\title{
Prion diseases and the gastrointestinal tract
}

\author{
Gwynivere A Davies ${ }^{1,2,3^{*}}$, Adam R Bryant BSc ${ }^{1,4^{*}}$, John D Reynolds $\mathrm{PhD}^{1,4}$, \\ Frank R Jirik MD FRCPC 5,6 , Keith A Sharkey $\mathrm{PhD}^{1,2,3}$
}

GA Davies, AR Bryant, JD Reynolds, FR Jirik, KA Sharkey. Prion diseases and the gastrointestinal tract. Can J Gastroenterol 2006;20(1):18-24.

The gastrointestinal (GI) tract plays a central role in the pathogenesis of transmissible spongiform encephalopathies. These are human and animal diseases that include bovine spongiform encephalopathy, scrapie and Creutzfeldt-Jakob disease. They are uniformly fatal neurological diseases, which are characterized by ataxia and vacuolation in the central nervous system. Alhough they are known to be caused by the conversion of normal cellular prion protein to its infectious conformational isoform $\left(\mathrm{PrP}^{\mathrm{sc}}\right)$ the process by which this isoform is propagated and transported to the brain remains poorly understood. $\mathrm{M}$ cells, dendritic cells and possibly enteroendocrine cells are important in the movement of infectious prions across the GI epithelium. From there, $\mathrm{PrP}^{\mathrm{sc}}$ propagation requires B lymphocytes, dendritic cells and follicular dendritic cells of Peyer's patches. The early accumulation of the disease-causing agent in the plexuses of the enteric nervous system supports the contention that the autonomic nervous system is important in disease transmission. This is further supported by the presence of $\mathrm{PrP}^{\mathrm{sc}}$ in the ganglia of the parasympathetic and sympathetic nerves that innervate the GI tract. Additionally, the lymphoreticular system has been implicated as the route of transmission from the gut to the brain. Although normal cellular prion protein is found in the enteric nervous system, its role has not been characterized. Further research is required to understand how the cellular components of the gut wall interact to propagate and transmit infectious prions to develop potential therapies that may prevent the progression of transmissible spongiform encephalopathies.

Key Words: Autonomic nervous system; Dendritic cells; Enteric nervous system; Lymphoreticular system; Prion

$\mathrm{T}$ ransmissible spongiform encephalopathies (TSEs) are a family of neurodegenerative diseases in which proteinaceous infectious agents, termed prions, accumulate in the central nervous system (CNS). TSEs have been documented in a variety of species, including Creutzfeldt-Jakob disease (CJD), variant CJD, kuru, Gerstmann-Sträussler-Scheinker syndrome and fatal familial insomnia in humans; chronic wasting disease in elk and mule deer; scrapie in sheep; and bovine spongiform encephalopathy (BSE) in cows. The discovery of several cases of BSE in cattle in Alberta (1) and chronic wasting disease in Saskatchewan and Alberta (2) has helped these diseases gain prominence in Canada in recent years, fuelling an increased

\section{Les maladies à prions et le tube digestif}

Le tube digestif joue un rôle important dans la pathogenèse des encéphalopathies spongiformes transmissibles. Il s'agit de maladies humaines ou animales, qui englobent notamment l'encéphalopathie spongiforme bovine et la maladie de Creutzfeldt-Jakob. Ce sont toutes des maladies neurologiques mortelles, qui se caractérisent par l'ataxie et la vacuolisation du système nerveux central. Même si l'on sait que la cause réside dans la transformation de la protéine normale du prion cellulaire en son isoforme conformationnelle infectieuse $\left(\mathrm{PrP}^{\mathrm{P}}\right)$, on en connaît bien peu sur le processus de propagation et de transport de la protéine vers le cerveau. Les cellules $\mathrm{M}$, les cellules dendritiques et peut-être les cellules entéro-endocriniennes sont des facteurs importants dans le passage des prions infectieux à travers l'épithélium gastro-intestinal. À partir de là, la propagation de la $\mathrm{PrP}^{\mathrm{x}}$ nécessite l'intervention des lymphocytes $\mathrm{B}$, des cellules dendritiques et des cellules dendritiques folliculaires des plaques de Peyer. L'accumulation précoce de l'agent pathogène dans les plexus du système nerveux entérique étaye l'assertion selon laquelle le système nerveux autonome joue un rôle important dans la transmission de la maladie. D'ailleurs, la présence de $\operatorname{PrP}^{\mathrm{x}}$ dans les ganglions des nerfs sympathiques et parasympathiques du tube digestif ne fait qu'ajouter du poids à l'assertion. De plus, le système lymphoréticulaire a été mis en cause comme voie de transmission de la protéine depuis l'intestin jusqu'au cerveau. Même si la présence de la protéine normale du prion cellulaire a été observée dans le système nerveux entérique, son rôle n'a pas été caractérisé. Il faudrait donc faire plus de recherche pour comprendre comment les constituants cellulaires de la paroi intestinale participent au processus de propagation et de transmission des prions infectieux et pour élaborer des traitements susceptibles de prévenir l'évolution des encéphalopathies spongiformes transmissibles.

${ }^{1}$ Institute for Infection, Immunity and Inflammation; ${ }^{2}$ Hotchkiss Brain Institute; ${ }^{3}$ Department of Physiology and Biophysics; ${ }^{4}$ Department of

Anatomy and Cell Biology; ${ }^{5}$ Alberta Bone and Joint Institute; ${ }^{6}$ Department of Biochemistry and Molecular Biology, University of Calgary,

Calgary, Alberta. *Equal contribution

Correspondence: Dr Keith Sharkey, Department of Physiology and Biophysics, University of Calgary, 3330 Hospital Drive Northwest, Calgary,

Alberta T2N 4N1. Telephone 403-220-4601, fax 403-283-3028, e-mail ksharkey@ucalgary.ca

Received for publication July 6, 2005. Accepted July 7, 2005 
its infectious misfolded counterpart, $\operatorname{PrPsc}(5,6)$. In all cases of TSE, the misfolded prion protein is eventually transmitted to the CNS, where it leads to neuronal cell death and the formation of protease-resistant aggregates (5). Why other somatic tissues fail to undergo degeneration in TSEs remains unclear, given that $\mathrm{PrP}^{\mathrm{c}}$, the 'template' from which $\mathrm{PrP}^{\mathrm{sc}}$ is formed, is so widely expressed. Prion protein is found in a variety of tissues, although its highest expression is in the CNS. Outside of the brain and spinal cord, the gastrointestinal (GI) tract, autonomic and sensory nerves, spleen, thymus, heart and testes also express high levels of $\operatorname{PrP}^{\mathrm{c}}(7)$. The role of $\mathrm{PrP}^{\mathrm{c}}$ is not known, although it has been suggested (8-10) that it regulates synaptic function in neurons, possibly by regulating copper metabolism. There is also some evidence $(11,12)$ suggesting that the prion protein may have a neuroprotective role in response to stimuli, such as oxidative stress.

Development of a murine model lacking the $\mathrm{PrP}^{\mathrm{c}}$-encoding gene was crucial for studying the normal physiological role of prion protein, as well as for demonstrating the necessity of endogenous $\mathrm{PrPc}^{\mathrm{c}}$ in prion propagation and disease induction. In all cases, following either oral ingestion or inoculation with infectious prions, transgenic mouse models lacking $\mathrm{PrP}^{\mathrm{c}}$ were found to neither accumulate nor circulate $\mathrm{PrP}^{\mathrm{sc}}$ except in singular, extremely rare cases, during which prion aggregates still developed, albeit at much lower levels than in wild-type scrapie-infected mice $(5,13-15)$. Thus, mice lacking the endogenous prion gene were found to be totally resistant to prion disease induction, regardless of the route of administration of the infective material. This finding represented a milestone in prion research and supported the infectious prion hypothesis of TSE pathogenesis.

Although TSEs manifest themselves primarily in the CNS of affected animals, the pathophysiology of TSEs does not exclusively involve components of the nervous system. It has been well documented $(3,16,17)$ that cells and organs of the immune system, while themselves apparently remaining largely unaffected by accumulation of $\operatorname{Pr} \mathrm{P}^{\mathrm{sc}}$, are key players in many of the pathophysiological events from the point of prion exposure to the accumulation of $\mathrm{PrPsc}^{\mathrm{sc}}$ in the CNS (18).

Early studies (16) linking the lymphoreticular system (LRS) to TSE pathogenesis involved splenectomy, thymectomy or genetic asplenia, or athymia in mice, and suggested that the spleen, not the thymus, was of crucial importance to scrapie pathogenesis in mice. Later, experiments (19) using severe combined immunodeficient mice further supported a role for lymphoid organs, because immunodeficiency significantly prolonged the disease's incubation time, and reconstitution with normal splenocytes was able to restore disease susceptibility (20). In studying human or animal TSEs, $\operatorname{PrPs}^{\mathrm{sc}}$ accumulation has been repeatedly demonstrated in cells and organs of the LRS, often before accumulation in the CNS (21-24). It has also been shown that $\mathrm{PrP}^{\mathrm{c}}$ expression by both stromal and hematopoietic components is important for optimal prion propagation and development of CNS disease (25). Acknowledging the importance of the LRS in TSE pathogenesis, recent research has focused considerable effort on characterizing the potential contributions of immune components in mediating infection, propagation and progression of TSEs.

While the role of the lymphoid system in TSE pathogenesis is unquestioned, components of the nervous system are also key players in disease progression. Recent research $(26,27)$ has documented prion entry into the CNS via the enteric nervous system (ENS), and in the autonomic and sensory innervation of the GI tract. Because PrPc expression is necessary to maintain prion disease, the high $\operatorname{PrPc}^{c}$ concentration found in enteric neurons and glial cells $(7,28)$ raises the possibility of the ENS playing a vital role in prion disease, by providing an initial site for infectivity and prion generation, and by aiding the retrograde transport of the communicable agent to the brain along the efferent innervation supplied to the ENS.

\section{ABSORPTION OF PRIONS FROM THE GI TRACT}

Most TSEs are acquired orally, wherein prion protein is ingested and subsequently absorbed $(29,30)$. However, despite its acknowledged importance, many aspects of the oral pathway of TSE transmission remain poorly understood (31).

The initial step, when prion protein transmigrates from the gut and into the lymphoid system, has been proposed to involve epithelial $\mathrm{M}$ cells, because these represent key sites of enteric antigen sampling by facilitating the entry and delivery of enteric pathogens into underlying lymphoid tissues via the process of transepithelial transport (32). An experiment in which artificial $\mathrm{M}$ cells, derived from carefully differentiated intestinal-like cells, were required for transepithelial prion transport in vitro indicated a role for $\mathrm{M}$ cells in prion absorption (33). However, there has been little additional research to further support this hypothesis, and the requirement for $\mathrm{M}$ cells in prion transport has yet to be documented using in vivo models.

Alternatively, prion absorption through the gut wall may involve enteroendocrine cells, which are scattered throughout the mucosa of the GI tract from the stomach to the rectum, and are responsible for endocrine and paracrine signalling in the GI tract (34). Due to their high basal concentration of secretory vesicles and their intimate relationship with enteric and extrinsic nerves located beneath the epithelium, these cells are more than adequately equipped to use transcytosis to convey prions across the epithelial barrier to nervous tissues. Enteroendocrine cells also express both $\operatorname{PrP}^{\mathrm{c}}$ messenger RNA and protein on a level comparable with that of enteric neurons (7), suggesting an additional role for these cells in prion amplification. However, the mechanisms by which these cells mediate transepithelial transport or prion amplification have yet to be elucidated, due in part to the focus on the role of $\mathrm{M}$ cells, lymphocytes and phagocytes in prion infection.

Peyer's patches (PPs), follicle clusters located along the mammalian intestine, are closely associated with $\mathrm{M}$ cells and have been implicated in early stages of prion pathogenesis following oral challenge. Researchers (24,35-39) have repeatedly observed early rises in PrPsc titres in PPs from a variety of species including mice, sheep, hamsters, deer, cattle and primates. In mouse models, reduced PP numbers have been linked to strong resistance to orally acquired prion infection (40). The evident contribution of PPs in prion pathogenesis has reinforced other research citing involvement of PP-localized cells in TSE, and has also turned attention to a more specific characterization of the contribution of PPs and PP cells in TSE progression.

\section{AMPLIFICATION AND REPLICATION OF PRIONS}

Between prion absorption and TSE manifestation in the CNS, there is an incubation period in which the ingested prion is replicated and amplified within the host. The replication 
phase can vary in length and nature depending on species, genotype, environment and host-specific factors (41).

Although some specific aspects of the pathophysiological step remain poorly characterized, there is general consensus that follicular dendritic cells (FDCs), located in germinal centres of mammalian PPs, play a key role at this point of disease progression. Researchers have characterized FDCs primarily as a source of prion replication, because prion proliferative centres have repeatedly been documented as postmitotic, longlived, low-density cells of stromal origin $(42,43)$. Further support for FDC-mediated prion replication comes from studies that have shown that $\mathrm{PrPc}^{\mathrm{c}}$, whose expression is a requirement for prion replication (6), is highly expressed by FDCs (44), and its pathogenic counterpart, $\mathrm{PrPsc}^{\mathrm{sc}}$, can be isolated from FDCs at early stages following peripheral infection (4446). Additionally, in mouse models, lack of functional FDCs has been linked to resistance to neuroinvasion following peripheral prion challenge (47-49). Combined, this evidence strongly suggests that FDCs are key sites of prion replication and accumulation during TSE pathogenesis. While it is possible that other types of replicative centres exist, FDCs remain the most widely accepted sites of prion replication.

\section{FROM THE GUT TO REPLICATIVE CENTRES}

FDCs are unquestionably prominent players in the lymphoid component of TSE pathogenesis, but recent research has suggested that additional lymphoid components, namely B cells and dendritic cells (DCs), may also bear some importance. While FDCs are known to be sites of PrPsc retention and replication, the mechanism by which $\mathrm{PrP}^{\mathrm{Ps}}$ reaches FDCs after crossing the intestinal barrier remains unclear (50).

\section{B cells}

A role for B cells, not $\mathrm{T}$ cells, in TSE pathogenesis was first suggested in early studies involving splenectomy, where it was shown that the spleen is of crucial importance to scrapie pathogenesis in mice (16). A recent important experiment by Klein et al (51) complemented these findings by showing that $B$ cell deficiencies in mice conferred resistance to scrapie after intraperitoneal injection.

However, in a follow-up experiment (52) by the same group, it was shown that $\mathrm{PrPc}^{\mathrm{c}}$ expression on $\mathrm{B}$ cells was not required for prion neuroinvasion, which, coupled with evidence that prion replication requires PrPc expression (6), suggested that B cells may play an indirect role in prion propagation. In light of these findings, it has been suggested that $\mathrm{B}$ cells may transport $\mathrm{PrP}^{\mathrm{sc}}$ to nerve endings in a $\mathrm{PrPc}$, independent manner; immunoglobulin-PrP complexes may facilitate the conversion of $\mathrm{PrPc}^{\mathrm{c}}$ to $\mathrm{PrP}^{\mathrm{sc}}$; or that $\mathrm{B}$ cell-secreted cytokines and immunoglobulins may somehow facilitate prion access to the nervous system $(51,52)$. To date, there has been little evidence to support such propositions. The most convincing and best supported evidence (31) has suggested that B cells are important mostly in FDC maintenance.

$B$ cells have well-documented roles in both the maturation and maintenance of FDCs within germinal centres, and do so mainly through secretion of tumour necrosis factor-alpha and lymphotoxin-alpha/beta $(\operatorname{LT} \alpha / \beta) \quad(53,54)$. Knockout mice devoid of LT $\alpha$, LT- $\beta$ or LT- $\beta$ receptor genes have shown reduced efficiency of prion propagation after peripheral exposure (47), and immunoglobulin-mediated pharmacological blocking of LT- $\beta$ receptor has been shown to impair TSE pathogenesis $(48,49)$, supporting assertions that B cell contributions may be limited to their roles in FDC maintenance. Further, in studying scrapie infection in mouse PPs, it was shown that reduced numbers of enteric lymphocytes, including the abundant B cells within PPs, did not reduce prion pathogenesis following oral infection (40). These observations, combined with evidence that prion replication occurs in mitotically inactive stromal cells $(42,43)$, suggest that B cells act primarily in support of the main lymphoid prion replicative centre, the FDC.

Because many aspects of prion transmission remain poorly characterized, it is too early to suggest that B cells contribute solely to FDC maturation during prion transmission. M cells, which were previously mentioned as candidates for absorption of prions across the gut wall, are dependent on intraepithelial B cells for maturation (31), potentially giving B cells an indirect role in enteric prion uptake. Additionally, because mechanisms for transmission of PrPsc from the gut to the sessile FDC, and for the subsequent transmission of $\mathrm{PrPsc}^{\mathrm{sc}}$ to the nervous system remain poorly understood $(31,50)$, it is not possible to conclusively rule out the mobile $\mathrm{B}$ cell as a candidate carrier in each of these processes. Little experimental evidence has supported such a role for B cells in prion pathogenesis, but the observation by Andreoletti et al (55) that $\mathrm{PrPsc}^{\mathrm{sc}}$ is detectable in sheep B follicles of PPs before appearing in FDCs provides some indication that $\mathrm{B}$ cells may have a variety of roles in $\mathrm{PrPsc}^{\mathrm{sc}}$ transport.

\section{DCs}

Recent searches for a cellular bridge for prion transmission between the gut and FDCs have directed attention to DCs, professional antigen sampling cells located immediately below the follicle-associated epithelium within PPs. DCs are found in both the lamina propria and in PPs, and are PrPc, positive hematopoietic system-derived cells that migrate through tissues and have a surveillance role. DCs are ideal candidates for the process in that they are abundant in follicular domes, where $\mathrm{M}$ cell-mediated enteric antigen sampling occurs (56). They are mobile and continuously migrate from the intestinal wall to mesenteric lymph nodes (57), and are capable of transporting antigens absorbed from the intestinal lumen (58). Experiments (59) investigating DCs in TSE transmission have shown that DCs are likely capable of transporting $\mathrm{PrP}^{\mathrm{sc}}$ from the gut to lymphoid prion replicative centres, though it has not been shown that DCs can transfer infectivity. It has also been shown that DCs residing in mesenteric lymph nodes can transport immunocomplexes from the subcapsular sinus to FDCs (60), and it has been suggested that DCs could transport $\mathrm{PrPsc}^{\mathrm{sc}}$ between lymphoid organs (61).

Mechanistically, DCs are known to transmit pathogenic molecules to FDCs through exosomal transfer, which would be a plausible mechanism for the transfer of the glycosylphosphatidylinositol-anchored prion protein from cell to cell because glycosylphosphatidylinositol-anchored proteins are preferentially transferred exosomally in lipid rafts $(50,62)$. A recent experiment by Defaweux et al (50) in mice using a double immunofluoresence staining showed the existence of cell to cell contacts between DCs and gut epithelium and between DCs and FDCs, providing further support for a role for DCs as a bridge between prion absorption and replication within the lymphoid system. 
However, recent research (63) using CD40 ligand-deficient mice, where DC migration is inhibited, observed unimpaired prion invasion, indicating that prion transport is not necessarily contingent on the migratory capacity of DCs. In light of these results, it was suggested that FDCs may directly acquire gut-absorbed prions from the surrounding environment, independent of DC-mediated prion transfer.

\section{Macrophages}

Studies of lymphoid TSE pathogenesis have also directed their attention toward macrophages and, unlike B cells, FDCs and DCs, it appears as though macrophages play a role in the clearance of prions from the host than in the propagation of infectivity. Macrophages were initially implicated in TSE pathogenesis when it was shown that prion replicative centres, like macrophages, express $\mathrm{PrP}^{\mathrm{c}}$ and are long-lived and radioresistant (64). Macrophages are additionally present in PPs, which have been previously mentioned as key sites for the uptake of orally administered prions in many species. A role for macrophages in prion clearance has been suggested by studies where it was shown that they carry PrPsc intralysosomally (65), that extended in vitro culture with macrophages that show they can reduce scrapie infectivity (66) and that in vivo macrophage depletion in mice quickens the rate of scrapie progression and increases accumulation of infectivity and $\mathrm{PrP}^{\mathrm{Ps}}$ in the spleen (67). A recent experiment by Maignien et al (68) further confirmed a role for macrophages in TSE resistance by using the macrophage-suicide technique to correlate the degree of BSE and scrapie resistance to amounts of PrPsc isolated from macrophages. Thus, there is reasonable evidence to suggest that macrophages are implicated in TSE pathogenesis and have primarily preventative roles, likely through the elimination of infective prion particles.

\section{THE ENS IN PRION DISEASES}

Vitally important for coordinating normal gut function, the ENS comprises a vast network of enteric neurons and nerve processes that are sustained by an even greater number of enteric glia, located in two major plexuses in the gut wall $(69,70)$. The two ganglionated plexuses are the submucosal plexus, located between the mucosa and circular muscle layer within the submucosa, and the myenteric plexus, found between the circular and longitudinal muscular layers of the wall of the alimentary canal. The ENS also receives both sympathetic and parasympathetic innervation and it has a rich primary afferent innervation from vagal and spinal afferents (70). Under hierarchical control of the CNS, the ENS receives input from autonomic nerves, which act as a potential conduit for transmission from the gut to the brain by axonal transport.

Enteric neurons have been found to express high levels of $\mathrm{PrP}^{\mathrm{C}}$ messenger RNA and protein in histologically normal specimens (7), implying a role for the ENS in prion diseases, because the conformational change of $\mathrm{PrPc}^{\mathrm{c}}$ to $\mathrm{PrPsc}^{\mathrm{Ps}}$ is essential to prion disease (5).

Although germinal centres of lymphoid follicles are acknowledged as being poorly innervated, ultrastructural studies have found a network of nerve fibres within PP nodules $(71,72)$, placing FDCs in close contact with nerve endings. It was previously postulated that the zone of lymphoid follicles innervated by terminal unmyelinated nerve fibres represented the entry into the autonomic nervous system (73), and recent evidence reinforcing the importance of FDCs supports this method of neuroinvasion.

DCs have also been implicated in neuroinvasion. Prion neuroinvasion is commonly accepted to proceed through nerves innervating PPs and draining lymph node of PPs and the spleen $(74,50)$. Defaweux et al $(50)$ observed cell to cell contacts between DCs and enteric nerve endings in PPs. Nerve fibres, like FDCs, are sessile, so in the absence of direct FDC-neuronal cell to cell connections, which were not observed, mobile DCs are an attractive candidate for bridging lymphoid prion accumulation and neuroinvasion.

There is already some evidence (75-78) that transmission of prions to the ENS occurs after oral challenge, as pathogenic $\mathrm{PrP}$ labelling is consistently found within the myenteric and submucosal plexuses and gut-associated lymphoid tissue, which includes PPs, at the earliest time of sacrifice after infection. Outbred Syrian hamsters orally infected with scrapie were sacrificed at various times between 69 days and 132 days postinfection; from the earliest time onwards, immunolabelling revealed $\mathrm{PrP}^{\mathrm{Ps}}$ in the ENS taken from the duodenal and ileal muscularis and submucosa (76), indicating the ENS as a potential site of replication and invasion.

It is also possible that $\mathrm{PrP}^{\mathrm{sc}}$ residing in intestinal PPs could pass into mesenteric lymph nodes and proceed to the brain via migrating cells of the LRS, thus completely bypassing the ENS (26). However, the early accumulation of the abnormal prion protein in the ENS argues against such a proposition.

\section{AUTONOMIC INNERVATION OF THE GI TRACT WITH RELATION TO PRIONS}

Although extensive enteric reflex arcs exist, the CNS retains autonomic control of the gut. Input regarding the luminal environment is carried to the CNS by extrinsic primary afferent (sensory) neurons, whose cell bodies are located in the nodose and dorsal root ganglia (70). Parasympathetic efferent signals moving away from the CNS are carried from the dorsal motor nucleus of the vagus and sacral parasympathetic nuclei in the spinal cord toward enteric neurons in the gut (70). Sympathetic efferent signals arise from neurons in the spinal cord, which synapse in the abdominal prevertebral ganglia (eg, celiac ganglion), from where the gut innervation is derived.

The role of the parasympathetic and sympathetic nerve trunks in PrPsc transmission have been increasingly regarded as a route for infective prions to enter the CNS (79), because $\mathrm{PrP}^{\mathrm{sc}}$ accumulation has been detected in the dorsal motor nucleus of the vagus nerve and the nodose, dorsal root and celiac ganglia $(75,80)$. To date, however, no one has performed vagotomy and assessed the extent of prion accumulation in the CNS following this lesion. It was previously unclear if other autonomic nerves found within the wall of the gut are capable of transmitting to the spinal cord, however, recent studies indicate a much wider range of $\mathrm{PrP}^{\mathrm{sc}}$ accumulation than that mediated solely via the vagus nerve. Thus, McBride and Beekes (75) found heavy labelling in the celiac-mesenteric ganglion complex and scant labelling in the vagus nerve, suggesting mainly sympathetic transport of $\mathrm{PrPsc}$. In contrast, Sigurdson et al (80) found heavy labelling in the vagus nerve and no apparent labelling in the celiac ganglion, suggesting parasympathetic transport. However, in both studies, the authors agreed that both the sympathetic and parasympathetic divisions of the autonomic nervous system likely play a role in transmission to the CNS. 


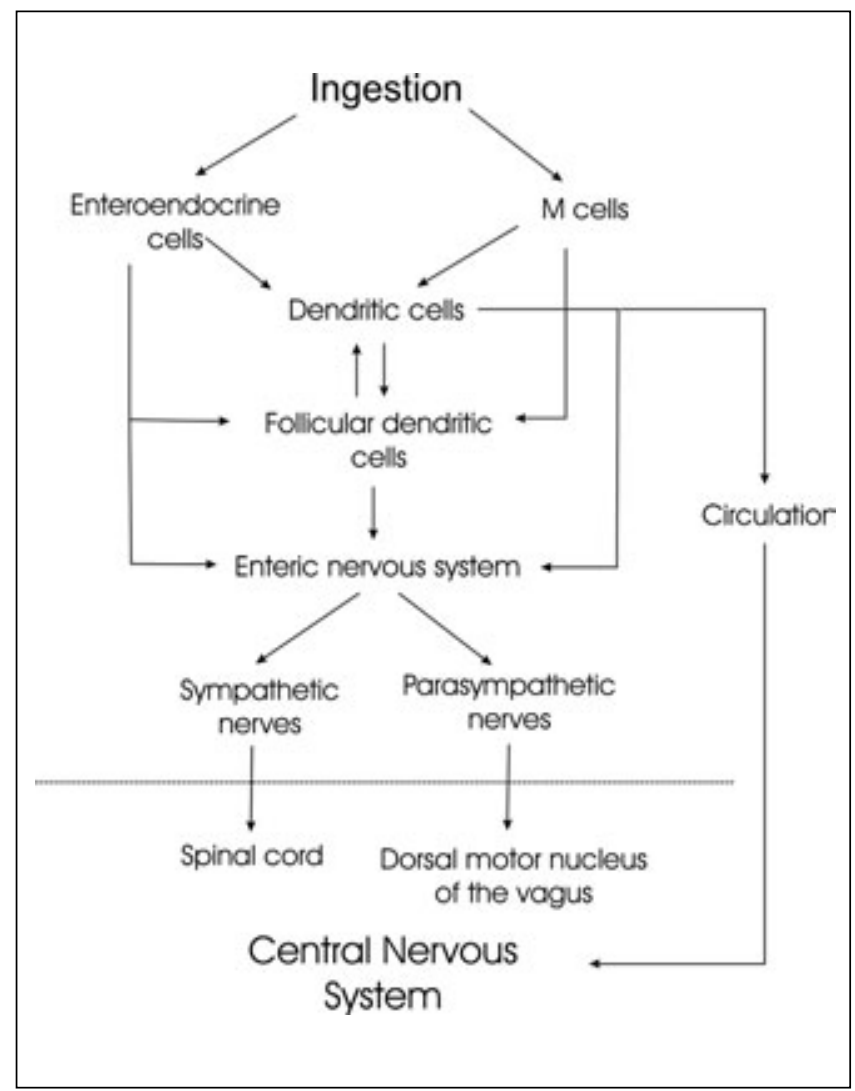

Figure 1) Possible routes of entry, propagation and neuroinvasion for cellular prion protein after introduction to the luminal environment of the gastrointestinal tract. M cells, dendritic cells and follicular dendritic cells are found in Peyer's patches. The dashed line indicates the central nervous system

\section{CONCLUSIONS}

The involvement of the immune and nervous system in the propagation and transmission of prions is summarized in Figure 1. While it is unquestionable that the lymphoid system is of crucial importance in TSE pathogenesis, many aspects regarding the nature of its contribution remain unclear.
However, there is reasonable consensus that FDCs act as primary prion replicative centres, but the details of the lymphoid system's roles in prion absorption, transmission to replicative centres, and in potentially mediating neuroinvasion remain uncertain.

Further research into the precise sequence of events involved in neuroinvasion from the ENS to the brain is required before definitive statements about the pathways of in vivo transmission can be made. The relative roles of enteric glia and enteric neurons as reservoirs of $\operatorname{PrPc}^{\mathrm{c}}$ remains an area for investigation, as well, the effect of removing extrinsic neural pathways in the susceptibility to prion disease needs to be examined. These experiments will help to define the involvement of the autonomic nervous system in disease transmission.

There have been no reports of a spontaneous GI phenotype in mice lacking the prion gene; however, it is unlikely that intestinal structure and physiology of the PrP knockout has been subjected to close scrutiny. Examination of brain and behavioural activity in mice lacking $\mathrm{PrP}^{\mathrm{c}}$ has helped shed light on the role of $\mathrm{PrP}^{\mathrm{c}}$ in the $\mathrm{CNS}(81-83)$. By analogy, it is possible that study of the ENS in $\mathrm{PrP}^{\mathrm{c}}$ knockout mice will elucidate a role for this protein in gut function. Hopefully, with further research into this area, a clearer idea of the role of $\operatorname{PrP}^{\mathrm{c}}$ within the gut will be revealed, which in turn may lead to a better understanding of the mechanism of prion propagation, and the necessity of $\mathrm{PrP}^{\mathrm{c}}$ to normal physiology.

The fatal nature of this disease, combined with the economic and political ramifications of TSEs in livestock, make the dissection of the mechanisms underlying infection and pathogenesis vitally important. A better understanding of the TSEs, and specifically, how prions infect organisms and how they spread is essential to the development of potential preventive measures and new treatments for this devastating disease.

ACKNOWLEDGEMENTS: Research in the authors' laboratories is supported by the Canadian Institutes of Health Research, the Canadian Genetic Diseases Network and the Alberta Agricultural Research Institute. GAD is supported by the O'Brien Centre for Bachelor of Health Sciences. FRJ and KAS are Alberta Heritage for Medical Research Medical Scientists and FRJ holds a Canada Research Chair award.

\section{REFERENCES}

1. Hoag H. BSE case rattles Canadian officials. Nature 2003;423:467.

2. Kahn S, Dube C, Bates L, Balachandran A. Chronic wasting disease in Canada: Part 1. Can Vet J 2004;45:397-404.

3. Lasmezas CI. The transmissible spongiform encephalopathies. Rev Sci Tech 2003;22:23-36.

4. Prusiner SB. The prion diseases. Brain Pathol 1998;8:499-513.

5. Prusiner SB. Novel proteinaceous infectious particles cause scrapie. Science 1982;216:136-44.

6. Bueler HR, Aguzzi A, Sailer A, et al. Mice devoid of PrP are resistant to scrapie. Cell 1993;73:1339-47.

7. Ford MJ, Burton LJ, Morris RJ, Hall SM. Selective expression of prion protein in peripheral tissues of the adult mouse. Neuroscience 2002:113:177-92

8. Brown DR, Qin K, Herms JW, et al. The cellular prion protein binds copper in vivo. Nature 1997;390:684-7.

9. Hornshaw MP, McDermott JR, Candy JM. Copper binding to the $\mathrm{N}$-terminal tandem repeat regions of mammalian and avian prion protein. Biochem Biophys Res Commun 1995;207:621-9.

10. Hornshaw MP, McDermott JR, Candy JM, Lakey JH. Copper binding to the $\mathrm{N}$-terminal tandem repeat region of mammalian and avian

prion protein: Structural studies using synthetic peptides. Biochem Biophys Res Commun 1995;214:993-9.

11. Brown DR, Schmidt B, Kretzschmar HA. Effects of oxidative stress on prion protein expression in PC12 cells. Int J Dev Neurosci 1997;15:961-72.

12. Brown DR, Schulz-Schaeffer WJ, Schmidt B, Kretzschmar HA. Prion protein-deficient cells show altered response to oxidative stress due to decreased SOD-1 activity. Exp Neurol 1997;146:104-12.

13. Prusiner SB, Groth D, Serban A, et al. Ablation of the prion protein $(\mathrm{PrP})$ gene in mice prevents scrapie and facilitates production of antiPrP antibodies. Proc Natl Acad Sci USA 1993;90:10608-12.

14. Sailer A, Bueler H, Fischer M, Aguzzi A, Weissmann C. No propagation of prions in mice devoid of PrP. Cell 1994;77:967-8.

15. Sakaguchi S, Katamine S, Shigematsu K, et al. Accumulation of proteinase $\mathrm{K}$-resistant prion protein $(\mathrm{PrP})$ is restricted by the expression level of normal $\mathrm{PrP}$ in mice inoculated with a mouseadapted strain of the Creutzfeldt-Jakob disease agent. J Virol 1995;69:7586-92.

16. Clarke MC, Haig DA. Multiplication of scrapie agent in mouse spleen. Res Vet Sci 1971;12:195-7. 
17. Dickinson AG, Fraser H, Meikle VM, Outram GW. Competition between different scrapie agents in mice. Nat New Biol 1972;237:244-5.

18. Aucouturier P, Carnaud C. The immune system and prion diseases: A relationship of complicity and blindness. J Leukoc Biol 2002; 72:1075-83

19. Fraser H, Brown KL, Stewart K, McConnell I, McBride P, Williams A. Replication of scrapie in spleens of SCID mice follows reconstitution with wild-type mouse bone marrow. J Gen Virol $1996 ; 77: 1935-40$

20. Lasmezas CI, Cesbron JY, Deslys JP, et al. Immune systemdependent and -independent replication of the scrapie agent. J Virol 1996;70:1292-5.

21. Bruce ME, McConnell I, Will RG, Ironside JW. Detection of variant Creutzfeldt-Jakob disease infectivity in extraneural tissues. Lancet 2001;358:208-9.

22. Hilton DA, Fathers E, Edwards P, Ironside JW, Zajicek J. Prion immunoreactivity in appendix before clinical onset of variant Creutzfeldt-Jakob disease. Lancet 1998;352:703-4. (Lett)

23. Muramatsu Y, Onodera A, Horiuchi M, Ishiguro N, Shinagawa M. Detection of $\mathrm{PrP}^{\mathrm{Sc}}$ in sheep at the preclinical stage of scrapie and its significance for diagnosis of insidious infection. Arch Virol 1994;134:427-32.

24. Terry LA, Marsh S, Ryder SJ, Hawkins SA, Wells GA, Spencer YI. Detection of disease-specific PrP in the distal ileum of cattle exposed orally to the agent of bovine spongiform encephalopathy. Vet Rec 2003;152:387-92

25. Kaeser PS, Klein MA, Schwarz P, Aguzzi A. Efficient lymphoreticular prion propagation requires $\operatorname{PrP}(\mathrm{c})$ in stromal and hematopoeitic cells. J Virol 2001;75:7097-106.

26. Ghosh S. Mechanism of intestinal entry of infectious prion protein in the pathogenesis of variant Creutzfeldt-Jakob disease. Adv Drug Deliv Rev 2004:56:915-20.

27. Weissmann C, Raeber AJ, Montrasio F, et al. Prions and the lymphoreticular system. Philos Trans R Soc Lond B Biol Sci 2001;356:177-84

28. Shmakov AN, McLennan NF, McBride P, et al. Cellular prion protein is expressed in the human enteric nervous system. Nat Med 2000;6:840-1.

29. Hadlow WJ, Kennedy RC, Race RE. Natural infection of Suffolk sheep with scrapie virus. J Infect Dis 1982;146:657-64.

30. Collinge J. Variant Creutzfeldt-Jakob disease. Lancet 1999:354:317-23

31. Aguzzi A, Heikenwalder M. Prions, cytokines, and chemokines: A meeting in lymphoid organs. Immunity 2005;22:145-54.

32. Neutra MR, Frey A, Kraehenbuhl JP. Epithelial M cells: Gateways for mucosal infection and immunization. Cell 1996;86:345-8.

33. Heppner FL, Christ AD, Klein MA, et al. Transepithelial prion transport by M cells. Nat Med 2001;7:976-7.

34. Raybould HE, Cooke HJ, Christofi FL. Sensory mechanisms: Transmitters, modulators and reflexes. Neurogastroenterol Motil 2004;16(Suppl 1):60-3.

35. Aguzzi A, Montrasio F, Kaeser PS. Prions: Health scare and biological challenge. Nat Rev Mol Cell Biol 2001;2:118-26.

36. Andreoletti O, Berthon P, Marc D, et al. Early accumulation of $\mathrm{PrP}(\mathrm{Sc})$ in gut-associated lymphoid and nervous tissues of susceptible sheep from a Romanov flock with natural scrapie. J Gen Virol 2000;81:3115-26

37. Herzog C, Sales N, Etchegaray N, et al. Tissue distribution of bovine spongiform encephalopathy agent in primates after intravenous or oral infection. Lancet 2004;363:422-8.

38. Maignien T, Lasmezas CI, Beringue V, Dormont D, Deslys JP. Pathogenesis of the oral route of infection of mice with scrapie and bovine spongiform encephalopathy agents. J Gen Virol 1999;80:3035-42.

39. Sigurdson CJ, Barillas-Mury C, Miller MW, et al. PrP (CWD) lymphoid cell targets in early and advanced chronic wasting disease of mule deer. J Gen Virol 2002;83:2617-28.

40. Prinz M, Huber G, Macpherson AJ, et al. Oral prion infection requires normal numbers of Peyer's patches but not of enteric lymphocytes. Am J Pathol 2003;162:1103-11.

41. Tranulis MA. Influence of the prion protein gene, Prnp, on scrapie susceptibility in sheep. APMIS 2002;110:33-43.

42. Clarke MC, Kimberlin RH. Pathogenesis of mouse scrapie: Distribution of agent in the pulp and stroma of infected spleens. Vet Microbiol 1984;9:215-25.
43. Fraser $\mathrm{H}$, Farquhar $\mathrm{CF}$. Ionizing radiation has no influence on scrapie incubation period in mice. Vet Microbiol 1987;13:211-23.

44. McBride PA, Eikelenboom P, Kraal G, Fraser H, Bruce ME. PrP protein is associated with follicular dendritic cells of spleens and lymph nodes in uninfected and scrapie-infected mice. J Pathol $1992 ; 168: 413-8$.

45. Kitamoto T, Muramoto T, Mohri S, Doh-Ura K, Tateishi J. Abnormal isoform of prion protein accumulates in follicular dendritic cells in mice with Creutzfeldt-Jakob disease. J Virol 1991;65:6292-5.

46. Brown KL, Stewart K, Ritchie DL, et al. Scrapie replication in lymphoid tissues depends on prion protein-expressing follicular dendritic cells. Nat Med 1999;5:1308-12.

47. Prinz M, Montrasio F, Klein MA, et al. Lymph nodal prion replication and neuroinvasion in mice devoid of follicular dendritic cells. Proc Natl Acad Sci USA 2002;99:919-24.

48. Mabbott NA, Williams A, Farquhar CF, Pasparakis M, Kollias G, Bruce ME. Tumor necrosis factor alpha-deficient, but not interleukin-6-deficient, mice resist peripheral infection with scrapie. J Virol 2000;74:3338-44.

49. Montrasio F, Frigg R, Glatzel M, et al. Impaired prion replication in spleens of mice lacking functional follicular dendritic cells. Science 2000;288:1257-9

50. Defaweux V, Dorban G, Demonceau C, et al. Interfaces between dendritic cells, other immune cells, and nerve fibres in mouse Peyer's patches: Potential sites for neuroinvasion in prion diseases. Microsc Res Tech 2005;66:1-9.

51. Klein MA, Frigg R, Flechsig E, et al. A crucial role for B cells in neuroinvasive scrapie. Nature 1997;390:687-90.

52. Klein MA, Frigg R, Raeber AJ, et al. PrP expression in B lymphocytes is not required for prion neuroinvasion. Nat Med 1998;4:1429-33.

53. Collinge J, Hawke S. B lymphocytes in prion neuroinvasion: Central or peripheral players? Nat Med 1998;4:1369-70

54. Gonzalez M, Mackay F, Browning JL, Kosco-Vilbois MH, Noelle RJ. The sequential role of lymphotoxin and B cells in the development of splenic follicles. J Exp Med 1998;187:997-1007.

55. Andreoletti O, Berthon P, Marc D, et al. Early accumulation of $\operatorname{PrP}(\mathrm{Sc})$ in gut-associated lymphoid and nervous tissues of susceptible sheep from a Romanov flock with natural scrapie. J Gen Virol 2000;81:3115-26.

56. Kelsall BL, Strober W. Distinct populations of dendritic cells are present in the subepithelial dome and T cell regions of the murine Peyer's patch. J Exp Med 1996;183:237-47.

57. Huang FP, MacPherson GG. Dendritic cells and oral transmission of prion diseases. Adv Drug Deliv Rev 2004;56:901-13.

58. Liu LM, MacPherson GG. Antigen acquisition by dendritic cells: Intestinal dendritic cells acquire antigen administered orally and can prime naive T cells in vivo. J Exp Med 1993;177:1299-307.

59. Huang FP, Farquhar CF, Mabbott NA, Bruce ME, MacPherson GG Migrating intestinal dendritic cells transport $\mathrm{PrP}(\mathrm{Sc})$ from the gut. J Gen Virol 2002;83:267-71.

60. Szakal AL, Holmes KL, Tew JG. Transport of immune complexes from the subcapsular sinus to lymph node follicles on the surface of nonphagocytic cells, including cells with dendritic morphology. J Immunol 1983;131:1714-27.

61. Burthem J, Urban B, Pain A, Roberts DJ. The normal cellular prion protein is strongly expressed by myeloid dendritic cells. Blood 2001;98:3733-8.

62. Denzer K, Kleijmeer MJ, Heijnen HF, Stoorvogel W, Geuze HJ. Exosome: From internal vesicle of the multivesicular body to intercellular signaling device. J Cell Sci 2000;113:3365-74

63. Mohan J, Bruce ME, Mabbott NA. Neuroinvasion by scrapie following inoculation via the skin is independent of migratory langerhans cells. J Virol 2005;79:1888-97.

64. Fraser H, Farquhar CF, McConnell I, Davies D. The scrapie disease process is unaffected by ionising radiation. Prog Clin Biol Res 1989;317:653-8.

65. Jeffrey M, McGovern G, Goodsir CM, Brown KL, Bruce ME. Sites of prion protein accumulation in scrapie-infected mouse spleen revealed by immuno-electron microscopy. J Pathol 2000;191:323-32.

66. Carp RI, Callahan SM. Effect of mouse peritoneal macrophages on scrapie infectivity during extended in vitro incubation. Intervirology 1982;17:201-7. 
67. Beringue V, Demoy M, Lasmezas CI, et al. Role of spleen macrophages in the clearance of scrapie agent early in pathogenesis. J Pathol 2000;190:495-502.

68. Maignien T, Shakweh M, Calvo P, et al. Role of gut macrophages in mice orally contaminated with scrapie or BSE. Int J Pharm 2005;298:293-304.

69. Furness JB, Costa M. The Enteric Nervous System. Edinburgh: Churchill-Livingstone, 1987.

70. Furness JB, Clerc N, Vogalis, F, Stebbing MJ. The enteric nervous system and its extrinsic connections. In: Yamada T, Alpers DH, Kaplowitz N, Laine L, Owyang C, Powell DW, eds. Textbook of Gastroenterology, 4th edn. Philadelphia: Lippincott Williams \& Wilkins, 2003:12-33.

71. Heggebo R, Gonzalez L, Press CM, Gunnes G, Espenes A, Jeffrey M. Disease-associated PrP in the enteric nervous system of scrapieaffected Suffolk sheep. J Gen Virol 2003;84:1327-38.

72. Glatzel M, Klein MA, Brandner S, Aguzzi A. Prions: From neurografts to neuroinvasion. Arch Virol Suppl 2000;(16):3-12.

73. Glatzel M, Aguzzi A. Peripheral pathogenesis of prion diseases. Microbes Infect 2000;2:613-9.

74. van Keulen LJ, Vromans ME, van Zijderveld FG. Early and late pathogenesis of natural scrapie infection in sheep. APMIS 2002;110:23-32.

75. McBride PA, Beekes M. Pathological PrP is abundant in sympathetic and sensory ganglia of hamsters fed with scrapie. Neurosci Lett 1999;265:135-8.
76. Beekes M, McBride PA. Early accumulation of pathological PrP in the enteric nervous system and gut-associated lymphoid tissue of hamsters orally infected with scrapie. Neurosci Lett 2000;278:181-4.

77. van Keulen LJ, Schreuder BE, Vromans ME, Langeveld JP, Smits MA. Scrapie-associated prion protein in the gastrointestinal tract of sheep with natural scrapie. J Comp Pathol 1999;121:55-63.

78. van Keulen LJ, Schreuder BE, Vromans ME, Langeveld JP, Smits MA. Pathogenesis of natural scrapie in sheep. Arch Virol Suppl 2000;16:57-71.

79. Bencsik A, Lezmi S, Baron T. Autonomic nervous system innervation of lymphoid territories in spleen: A possible involvement of noradrenergic neurons for prion neuroinvasion in natural scrapie. J Neurovirol 2001;7:447-53.

80. Sigurdson CJ, Spraker TR, Miller MW, Oesch B, Hoover EA. PrP (CWD) in the myenteric plexus, vagosympathetic trunk and endocrine glands of deer with chronic wasting disease. J Gen Virol 2001;82:2327-34.

81. Lipp HP, Stagliar-Bozicevic M, Fischer M, Wolfer DP. A 2-year longitudinal study of swimming navigation in mice devoid of the prion protein: No evidence for neurological anomalies or spatial learning impairments. Behav Brain Res 1998;95:47-54.

82. Tobler I, Deboer T, Fischer M. Sleep and sleep regulation in normal and prion protein-deficient mice. J Neurosci 1997;17:1869-79.

83. Tobler I, Gaus SE, Deboer T, et al. Altered circadian activity rhythms and sleep in mice devoid of prion protein. Nature 1996;380:639-42. 


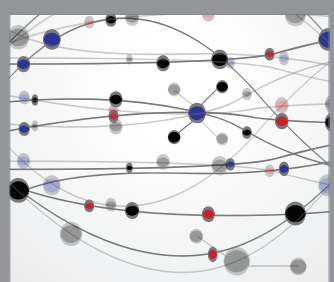

The Scientific World Journal
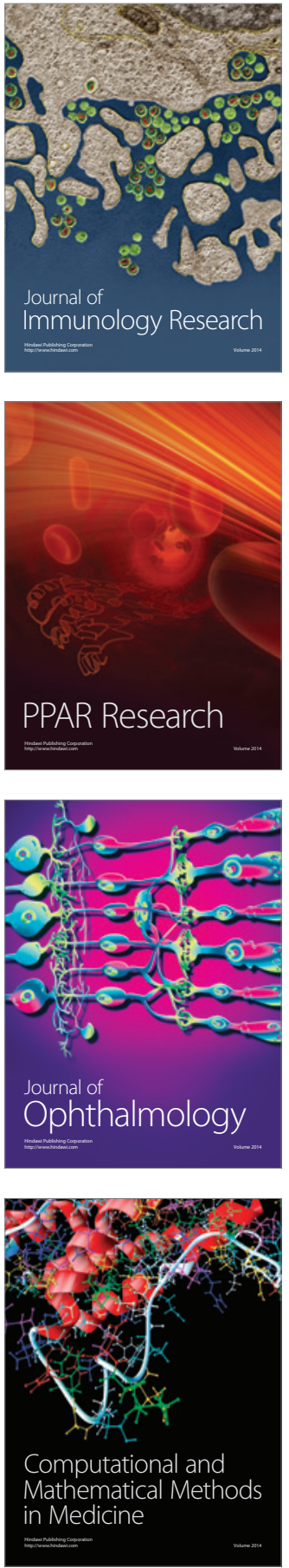

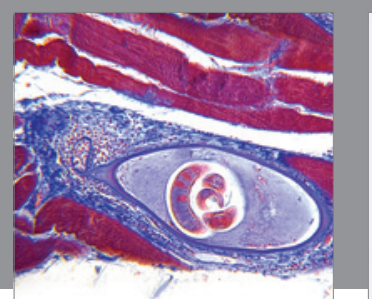

Gastroenterology Research and Practice

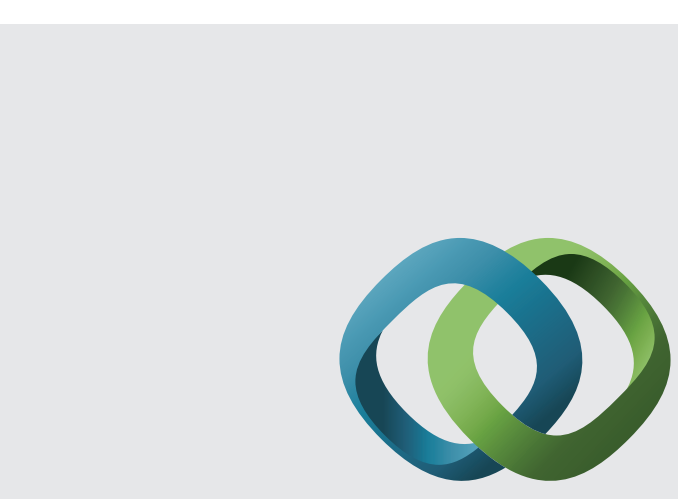

\section{Hindawi}

Submit your manuscripts at

http://www.hindawi.com
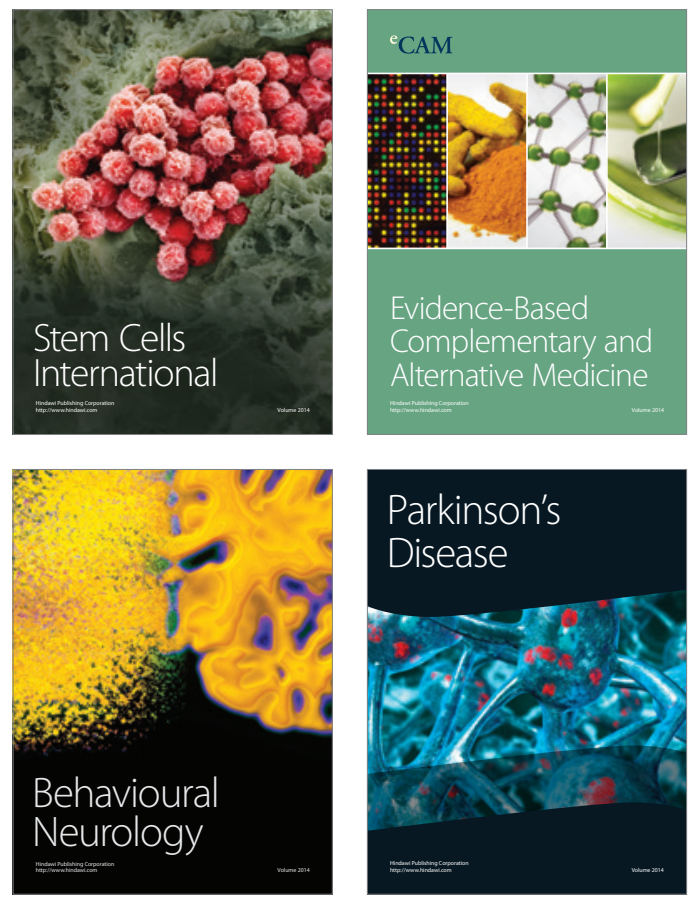
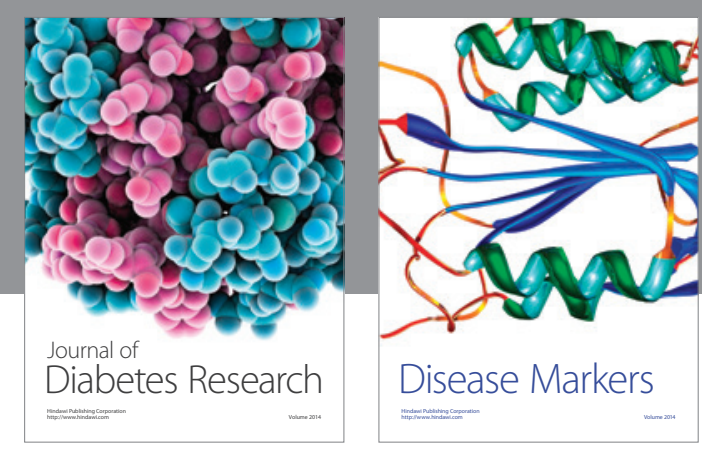

Disease Markers
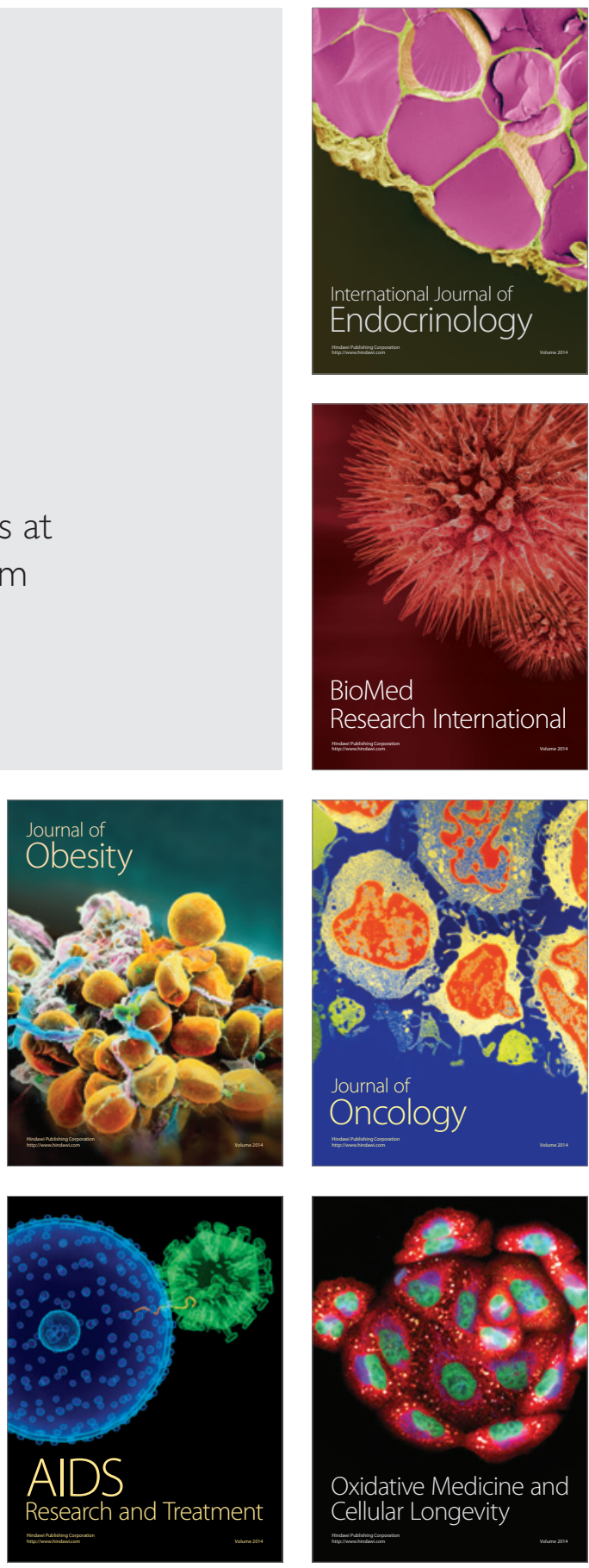